\title{
Does Cooperative Learning as a Teaching Approach Enhances Teaching and Learning in Integrated Culturally Diverse School Settings? An Exploratory Study
}

\author{
Gregory Alexander \\ Department Psychology of Education, \\ Faculty of Education, \\ University of the Free State, South Africa \\ alexanderg@ufs.ac.za \\ Micheal M van Wyk
}

Department of Curriculum and Instructional Studies, School of Teacher Education, College of Education, University of South Africa, Pretoria vwykmm@unisa.ac.za

\section{Doi:10.5901/mjss.2014.v5n2p689}

\begin{abstract}
Cooperative learning is a philosophical and practical approach to change classrooms settings and school organizations, classroom processes and learning activities in order to offer all learners more active learning experiences, equal opportunities, access, and a more social supportive role. This article explores cooperative learning (CL) as a learner centeredness teaching approach in enhancing teaching and learning in integrated culturally diverse ecologies in the Northern Cape province of South Africa. A survey was designed to explore teachers' views regarding the value of the cooperative learning approach in enhancing quality teaching and learning. Findings of this investigation revealed that educators viewed their lack of understanding the use of CL as teaching approach as a challenge in enhancing effective teaching and learning opportunities in culturally diverse settings. Participants alluded to issues with regard to the school curriculum, lesson presentation and interaction as their biggest challenge. Suggestions are formulated to empower in-service teachers in CL as a teaching approach. This investigation which was conducted as an exploratory value-based study forms part of the first phase of a funded project.
\end{abstract}

Keywords: Cooperative learning, integrated school environments, exploratory study, Northern Cape province

\section{Introduction}

Le Roux (1997) posits that a separate fragmented, system dominated by a Christian National Education ideology in South Africa has primarily been responsible for the transmission, interpretation and reproduction of cultural values, norms and heritage of the dominant group (White South Africans). Within the post-apartheid period (1994), the admission and integration of learners from different race - and cultural backgrounds to ex-model C schools (former white schools) became evident. The subsequent consequence of this trend implied that educators, especially white educators are now challenged of teaching black learners in integrated learning environments (Alexander, 2004). Furthermore Meier (2005) and Mpisi (2010) argue that some of the black learners who were integrated into former white schools find it difficult to adjust to the new educational contexts because they seemingly lack the language skills and required background to deal with the curriculum content, medium of instruction and teaching approaches of the Euro-and learner centred predominantly white educator staff component. This state of affairs may result in cultural misunderstandings and the consequent breakdown of educator-learner relations. White educators, representing the majority of the staff complement in Northern Cape schools (Kivedo 2006), which is apparently also the study demarcation for this study, are seemingly disempowered to deal with educational issues because they apparently lack the teaching skills, the Africanisation of learning content and strategies to facilitate meaningful teaching and learning experiences. As a response to the latter and not shifting the blame to the functioning and operation of these integrated school environments, we argue for the enhancement of conducive teaching contexts via cooperative learning. We further contend that cooperative learning is a 
culturally sensitive pedagogical and social learning approach that benefits all students and black students in particular (Haynes \& Gebreyesus 1992).

First, we briefly outline social constructivism as theoretical frame for this study. Thereafter, cooperative learning within the integrated cultural diverse context of the Northern Cape province is conceptualised. Further, we explore the value of cooperative learning in enhancing teaching and learning outcomes for integrated school settings of the Northern Cape province.

\section{Theoretical Frame}

Social constructivism emphasizes how meaning and understanding grow out of social encounters. It is within this constructivist paradigm that the cognitive load and information processing are related to the learning environment that actualizes one's potential (Learning Theories 2008). This learning theory therefore implies that learners are encouraged to construct their own knowledge in realistic situations with others instead of in de-contextualised, formal situations where they work on their own. It is crucial for educators, especially those in integrated school settings, to build new knowledge upon the basis of learners' previous learning experiences. The latter position might be viewed as a mechanism acknowledging learners' active participation in problem-solving and critical-thinking abilities in cooperative learning activities which they could find relevant and engaging (Jonassen et al. 1999). In order for educators operating in cultural diverse integrated school settings of the Northern Cape province, it becomes imperative for them to have a good foundation of the teaching needs and the steady development of skills and attitudes necessary to sustained learning.

\section{Conceptualization of Cooperative Learning within Integrated Cultural Diverse School Settings}

It needs to be noted that cooperative learning is not the consequence of any single stream of educational thought or movement (Van der Horst \& McDonald 1997). The original idea thereof goes back as far as the ancient Greek philosophers whilst Kegan (1998) argues that cooperative learning is as old as education itself. Cooperative learning rests on the philosophy of John Dewey (1961) and his belief that democracy in schools must be promoted in order to develop good citizenship amongst children. Slavin (1987a) started researching the specific application of cooperative learning in the classroom as early as 1970 with special emphasis on the fostering of interpersonal relationships amongst diverse ethnic groups. In the 1980s cooperative learning was characterised especially by research focusing on the models of Robert Slavin (1983) and David and Roger Johnson (1987). In the 1990s David and Robert Johnson applied their research in the classroom with cooperative learning as a teaching strategy in order to articulate the goals fundamental to the improvement of performance and the development of social skills for group work and the establishment of cooperative classroom communities. Furthermore, Robert Johnson focused particularly on the effect of cooperative learning in improving academic performance. Organising groups to work together is not a new practice in education. The use of group work projects is a common occurrence globally. Research also points to the effective and efficient use of group work in the USA (Aronson et al. 1978), England (Smith 2000), Canada (Ziegler 1981), Australia, West Germany and Nigeria (Okebukola 1985).

Cooperative learning is viewed as a teaching method whereby learners work together so that the group members can gain a joint benefit from the group activity. Johnson and Johnson (1992) point out that, "Without the cooperation among individuals, no group, no family, no organization and no school would be able to exist". Johnson, Johnson \& Holubec (1994) also contends that cooperative learning is the instructional use of small groups through which learners work together to maximize their own and each other's learning. Moreover, Slavin (1980) posits that cooperative learning refers to classroom techniques in which learners work on learning activities in small groups and accordingly receive rewards or acknowledgement for their collective effort. Therefore, within a cooperative learning class context, learners as group members organise and structure activities related to a specific assignment and/or project in such a manner that all group members can collaboratively work together. The set goals and the achievement of outcomes benefit the entire group of learners.

Cooperative learning as a teaching strategy promotes mutual respect and an understanding of learners' individuality. Aspects such as human rights, inclusiveness, and environmental and social justice, as determined by the Constitution of the Republic of South Africa, Act 108 of 1996 (NDE 2003a) are addressed in this manner. Lotan \& Whitcomb (1998) are also convinced of the use of cooperative learning as a sound approach to teaching in promoting academically, physically, ethnically and linguistically heterogeneous classrooms. The latter serves as premise for the use of cooperative learning in cultural diverse classroom settings of the Northern Cape province of South Africa. Sapon- 
Shevin and Schniedewind (1992) state that cooperative learning can foster educational excellence for all children regardless of class, race or gender, and may even provide learners and educators with the experience and expectation of active participation in controlling and changing the spheres of their lives. Furthermore, Johnson, Johnson and Smith (1998) are of the opinion that cooperative learning is the teaching-learning method for small groups by means of which cooperation amongst learners is facilitated with the aim of improving the learning experience. Educators who introduce cooperative learning to co-educators may in the process also assist these individuals in approaching their teaching tasks in a different manner and in this process also contributing to the enhancement of personal growth and professional development initiatives.

Cooperative learning is a philosophical and practical approach to changing classroom and school organisation, classroom processes and learning activities in order to offer all learners more active learning experiences, equal opportunities, access, and a more social supportive role (Slavin 1987a). Felder and Brent (2001) believe that teachers use cooperative learning as an instrument to involve learners in their own learning, and as a method of promoting social interaction skills amongst learners. Related to the latter Nastasi and Clements (1991) view cooperative learning as a group learning process, built on the belief that learn better when they learn together.

With the above said in mind, this paper attempts to explore the value of cooperative learning in enhancing teaching in integrated school environments of the Northern Cape province. In attempting the latter said it becomes crucial that the value op cooperative learning in enhancing teaching and learning be explored.

\section{Value of Cooperative Learning in Enhancing Teaching and Learning Outcomes for Integrated School Settings of the Northern Cape Province.}

Various researchers amongst the leading proponents of cooperative learning such as Johnson \& Johnson (1974), Slavin (1980) and Sharan (1990) hold the opinion that learners who are engaged on a task in small cooperative groups tend to master material better, feel better about themselves and are more accepting of classmates who are different from them. Therefore, learners who are more individually inclined may have a disposition in forging relationships and mastering learning material in a cultural diverse context such as the Northern Cape province of South Africa

Johnson et al. (1994) postulate that the nature of cooperative learning involves much more than regular group work, students, discussing material or the sharing of knowledge with each other. The successful implementation for cooperative in any type of school setting is dependable on certain outcomes. We will now attempt to give an exposition of the most pertinent issues relating to the enhancement of cooperative leaning outcomes.

The outcomes crucial to the enhancement of cooperative learning in integrated cultural diverse school setting are now briefly explained.

\section{- Embracing positive interdependence during cooperative learning team work activities}

The development and maintenance of positive interdependence during team work activities may assist them to transcend the gender, racial, cultural, linguistic and other differences they hold (Dumas 2003). Positive interdependence is further viewed as the relationship between members of a cooperative group and the degree to which participants perceive they are interdependent in that they share a mutual goal and that success is mutually achieved (Putnam 1998). This relationship can only be created if the group members have common goals; the work is distributed amongst the members; resources, information and material are shared amongst all learner group members; various roles and responsibilities are assigned to different members and the group is rewarded jointly. This issue is critical to integrated cultural diverse school settings in the Northern Cape province where educators need to master the skill of planning their lessons around common goals which could benefit any specific learning activity. Apart from interdependency amongst learners as group members, a cooperative learning group also implies that group members influence one another (Johnson et al. 1994): Acceptance by the peer group is of cardinal importance, and cooperative learning conditions almost "force" learners to accept one another, since they are dependent on one another.

\section{- Instilling the heterogeneous group interaction during the cooperative learning process}

Peer group interaction is an important element of the cooperative learning process, promotes the discovery and development of higher quality teaching and learning strategies. Pertaining to their social background, ability and skills levels, gender profile and physical competencies, heterogeneous learner groupings, especially those in integrated, 
cultural diverse school settings such as the Northern Cape province, are viewed as most effective in classroom activity (Slavin 1987b; Johnson et al.1994). In relation to the latter, Johnson and Johnson (1986) identify three ways in which the group interaction process amongst learners can take place. Learners compete with one another to determine who is the best (competitive goal structure), or they work on their own to achieve a goal (individualistic goal structure), or they work together to achieve a common goal (cooperative goal structure), after which the group as a whole is rewarded. Face-toface communication or social interactions are further regarded as cardinal to the process of cooperative learning. Learners in integrated schools settings could by means of verbal and/or non-verbal communication interaction directly with each other.

\section{- Acknowledging individual learning performance}

The purpose of any learning activity, whether it is in predominant mono-cultural or cultural diverse type of schooling is to pursue maximum individual learning performance and fostering understanding for group cohesion during the teaching and learning situation. Feedback mechanisms are necessary to determine each learner's mastery level, if learners are expected to support and help one another. Individual responsibility of each group member contributes to the eventual success of the group and is viewed as an essential prerequisite for the promotion of an effective cooperative learning environment (Slavin 1987b) Smith (1987) assigns responsibility for the learning process in cooperative learning where it belongs - namely to the learner.

\section{- Developing interpersonal and small-group skills amongst learners in the cooperative learning environment}

Learners in integrated schools as evident in the Northern Cape province, need to be guided by educators in the use of appropriate social skills getting to know each other, trust building and conflict resolution and accepting and supporting each other- these interactions might enhance a productive and constructive learning environments (Johnson \& Johnson in Killen 2007; Putnam 1998). The educator cannot expect learners to work together effectively as a group if they do not possess the necessary interpersonal and social skills. The fact that the teacher purposefully structures a cooperative learning situation is no guarantee that the cooperative learning process will take place effectively. A high-level of cooperation is necessary amongst learners so that they can work together to plan the interaction process and decide how projects will be assigned to each group member (Taylor 1991).

\section{- Educator attitude and motivation in applying class based cooperative learning approaches}

According to Artzt and Newman (1990) the implementation of cooperative learning as a teaching approach depends on a positive attitude towards such a teaching strategy within the classroom, otherwise it will not achieve the intended goal. This in itself might lead to the class educator achieving success and becoming extremely motivated in class activities. The role of the educator is to act as facilitator and role model offering support and assistance to all learner group members (Davidson \& O'Leary 1990). Furthermore educators could become most effective in the teaching-learning situation by providing guidance and guidelines to learners as a means of promoting cooperation and mutual interaction within every group.

\section{- Enhancing positive attitudes and relationships amongst learners in promoting diversity, human rights and} social justice

Cooperative learning as a teaching approach promotes mutual respect and an understanding of learners' diversity. The national school curriculum for South African schools addresses aspects such as human rights, inclusiveness, and environmental and social justice, as determined by the Constitution of the Republic of South Africa, Act 108 of 1996 (NDE 2003b). Educators in integrated cultural diverse schools are therefore obligated to teach the contents related to the afore mentioned aspects in a learner centered way- this as such necessitates learners to become actively involved in the learning process. Learners who are active participants in cooperative learning activities receive more social support from the group within a group context (Johnson et al. 1994). Moreover, group members experience more positive self-esteem based on self-acceptance by the other group members. Positive self-esteem leads to learners feeling better about 
themselves "from being liked, accepted and connected" (Kohn 1991). Positive relationships and attitudes could therefore be cultivated amongst learners.

\section{- Developing and learning life skills in the cooperative learning context}

Various authors such as Van der Horst and McDonald (1997), Hanekom and Nel (1991) and Taylor (1991) state that the educator's main responsibility especially as it relates to the Northern Cape school situation is to teach, develop and empower learners in life skills as a prerequisite for the cooperative learning situation. These authors further propagate that the teaching of life skills should include but not be limited to the following issues such as communication skills (language enrichment and reporting); the establishment and maintenance of a climate of trust in learner groups; the settling of differences amongst one another and making a constructive contribution to the group and developing research skills. Learners must develop skills as determined by the curriculum and those that are needed to function as a responsible citizen. Interaction amongst learners with diverse capabilities therefore implies that they work together to plan, think and make decisions in respect of the task or activity at hand.

\section{- Fostering sound reasoning skills and thought processes amongst learners}

Within the South African school diverse context, the educator is tasked of guiding all learners in a democratic and responsible way. Social, psychological and cognitive skills must be developed in terms of the aims of the national curriculum. The assumption hold by the education authorities is that learners' involvement in cooperative learning activities, might enhance their higher-order reasoning skills which are needed deep and sophisticated debate and discussion amongst group members (Khumalo 2001). Manera and Glockhamer (1989) concur with the latter position and state that learners involvement as active participants in cooperative learning group discussions, support the development of higher reasoning strategies such as interpretation, analysis, evaluation and application.

\section{Research Methodology}

Participants for this exploratory research study, a purposive sampling method was applied to educators drawn from a population of 200 high school teachers. A total of 148 educators from 10 integrated schools completed the questionnaires on the use of cooperative learning as teaching tool.

Instruments: A self-structured questionnaire, devised on the basis of an extensive study of the relevant literature, was distributed to 200 high teachers. A total of 148 of the 200 in integrated school contexts of the Northern Cape province, completed the questionnaires. The questionnaire was based on a 4-point Likert scale aimed at determining the perceptions of white educators regarding the use of cooperative learning as a teaching tool.

Procedure and data analysis: The relevant education authorities and participants were informed about the aim of the study. These parties gave formal consent prior to the commencement of the study. Educator participants completed the questionnaires. For the questionnaires, data analysis was executed in descriptive form using the Statistical Package for the Social Sciences. The overall reliability Cronbach alpha coefficient for this questionnaire was 0.9061 .

\section{Results}

In terms of section A of the questionnaire (Biographical information) $42 \%$ of the educator participants were male, while $58 \%$ were female. Regarding teaching experience, $69 \%$ of educators have less than 10 years, $38.6 \%$ have between 11 20 years teaching and $9.5 \%$ educators have between $21-30$ years. A total of $83.1 \%$ of educators has a professional teaching qualification.

The results for section B (White educators perceptions regarding the use of cooperative learning as a teaching tool) of the questionnaire have been presented in the following tables 1 and 2. 
Table 1. Achievement of cooperative learning (CL) outcomes via cooperative learning activities $(n=148)$

\begin{tabular}{|c|c|c|c|c|c|c|c|c|c|c|}
\hline \multirow[b]{2}{*}{ Items } & \multirow{2}{*}{$\begin{array}{c}X^{2} \\
\text { value }\end{array}$} & \multirow{2}{*}{$\begin{array}{c}\mathrm{p}- \\
\text { value }\end{array}$} & \multicolumn{2}{|c|}{$\begin{array}{l}\text { Not at } \\
\text { all }\end{array}$} & \multicolumn{2}{|c|}{$\begin{array}{l}\text { Small } \\
\text { extent }\end{array}$} & \multicolumn{2}{|c|}{$\begin{array}{l}\text { Large } \\
\text { extent }\end{array}$} & \multicolumn{2}{|c|}{$\begin{array}{c}\text { Very large } \\
\text { extent }\end{array}$} \\
\hline & & & $f$ & $\%$ & 1 & $\%$ & $\mathrm{f}$ & $\%$ & $f$ & $\%$ \\
\hline 1. Improving learner performance & 2.181 & 0.902 & 1 & 0.7 & 11 & 7.4 & 41 & 27.7 & 95 & 64.2 \\
\hline 2. Enhancing intergroup relationships & 3.905 & 0.866 & 2 & 1.4 & 13 & 8.8 & 46 & 31.1 & 87 & 58.8 \\
\hline $\begin{array}{l}\text { 3. Encouraging positive interaction amongst } \\
\text { learners of all racial groups }\end{array}$ & 3.683 & 0.945 & 2 & 1.4 & 10 & 6.8 & 37 & 25.0 & 99 & 66.9 \\
\hline 4. Instilling individual responsibilities & 7.756 & 0.758 & 1 & 0.7 & 18 & 12.2 & 40 & 27.0 & 89 & 60.1 \\
\hline 5. Supporting face to face interaction & 3.687 & 0.719 & 1 & 0.7 & 8 & 5.4 & 50 & 33.8 & 89 & 60.1 \\
\hline 6. Encouraging social and small group skills & 1.520 & 0.823 & 0 & 0.0 & 14 & 9.5 & 48 & 32.4 & 86 & 58.1 \\
\hline 7. Teaching about diversity and human rights & 3.685 & 0.815 & 2 & 1.3 & 16 & 10.8 & 47 & 31.7 & 83 & 56.0 \\
\hline 8. Attempting critical pedagogical approaches & 6.315 & 0.889 & 1 & 0.7 & 8 & 5.4 & 48 & 32.4 & 91 & 61.5 \\
\hline 9. Infusing issues of social justice in lessons & 2.258 & 0.689 & 5 & 3.3 & 13 & 8.7 & 53 & 35.8 & 77 & 52.1 \\
\hline 10. Promoting different learning styles & 3.634 & 0.728 & 4 & 2.7 & 23 & 15.5 & 39 & 26.3 & 82 & 55.4 \\
\hline 11. Using various cooperative learning methods & 3.783 & 0.789 & 3 & 2.0 & 18 & 12.1 & 43 & 29.1 & 84 & 56.7 \\
\hline
\end{tabular}

In table 1, the significance of the p-values for all cooperative learning outcomes is greater than 0.5 meaning the extent to which cooperative learning outcomes can be achieved by the implementation of cooperative learning activities in integrated school environments, is not statistically significant for this question. The majority of participants indicated that improving learner performance (64.2\%), enhancing intergroup relationships (58.8\%), encouraging positive interaction (66.9\%), instilling individual responsibilities (60.1\%), supporting face to face interaction (60.1\%), encouraging social and small group skills (58.1\%), teaching about diversity and human rights (56.0\%), attempting critical pedagogical approaches (61.5\%), infusing issues of social justice in lessons (52.1\%), promoting different learning styles (55.4\%) and using various cooperative learning methods (56.7\%) can to a very large extent achieve the cooperative activities for effective teaching in integrated learning environments.

Table 2: Experience in cooperative learning techniques in diverse classroom $(n=148)$

\begin{tabular}{|c|c|c|c|c|c|c|c|c|c|c|}
\hline \multirow[b]{2}{*}{ Items } & \multirow{2}{*}{$\begin{array}{c}X^{2} \\
\text { value }\end{array}$} & \multirow{2}{*}{$\begin{array}{c}\mathrm{p}- \\
\text { value }\end{array}$} & \multicolumn{2}{|c|}{$\begin{array}{c}\text { Not at } \\
\text { all }\end{array}$} & \multicolumn{2}{|c|}{$\begin{array}{l}\text { Small } \\
\text { extent }\end{array}$} & \multicolumn{2}{|c|}{$\begin{array}{l}\text { Large } \\
\text { extent }\end{array}$} & \multicolumn{2}{|c|}{$\begin{array}{l}\text { Very large } \\
\text { extent }\end{array}$} \\
\hline & & & $f$ & $\%$ & $\mathrm{~F}$ & $\%$ & $\mathrm{f}$ & $\%$ & $\mathrm{~F}$ & $\%$ \\
\hline $\begin{array}{l}\text { Discussed cooperative learning with other teachers and } \\
\text { tried some of their ideas in the classroom }\end{array}$ & 6.457 & .374 & 66 & 44.6 & 40 & 27.0 & 34 & 23.0 & 8 & 5.4 \\
\hline $\begin{array}{l}\text { Participated in an after-school in-service workshop on } \\
\text { cooperative learning }\end{array}$ & 12.809 & $.012^{*}$ & 25 & 16.3 & 28 & 18.9 & 56 & 37.8 & 39 & 26.4 \\
\hline Participated in a district teachers' seminar day & 3.416 & 878 & 21 & 14.2 & 30 & 20.3 & 58 & 39.2 & 39 & 26.4 \\
\hline Took a credit course at a higher learning institute & 5.373 & $.017^{\star}$ & 40 & 27.0 & 32 & 21.6 & 37 & 25.0 & 39 & 26.4 \\
\hline Attended an NGO workshop on cooperative learning & 5.489 & .704 & 42 & 28.4 & 45 & 30.4 & 31 & 20.9 & 30 & 20.4 \\
\hline Read an article on cooperative learning & 4.111 & $.002^{\star}$ & 63 & 40.8 & 37 & 25.0 & 34 & 23.0 & 14 & 10.2 \\
\hline
\end{tabular}

In table 2, the significance of the p-value for "participated in an after-school in-service workshop" $(0.012>0.05)$, "took a credit learning course" $(0.017>0.05)$ and "read an article on Cooperative learning" $(0.002>0.5)$ are statistically significant because these educators in Cooperative learning will enhance their teaching in integrated school environments. Participants also indicated that to a large extent they had participated in an after-school in-service workshop on cooperative learning (37.8\%) and in an educational district educators' seminar day (39.2\%), while to a very small extent they had attended a NGO workshop on cooperative learning (30.4\%). Furthermore, $44.6 \%$ of participants indicated that they had never discussed cooperative learning with other teachers or tried some of the ideas in the classroom, while $40.8 \%$ had never read an article on cooperative learning and $27 \%$ had not taken any credit bearing course at the level of higher learning. In terms of the focus group interviews, $52 \%$ of the learner participants were male while $48 \%$ were female. All these learners selected for the focus groups were black- the aim of this study was particularly also to gather their views regarding issues during the teaching situation. 
Comparison between the $t$-test scores of the experiences in cooperative learning techniques in culturally diverse classrooms. Based on information and results in Tables 3 and 4 regarding $t$-test scores between educators experiences in cooperative learning techniques in culturally diverse classrooms which is displayed, statistically.

Table 3. Gender Mean and standard deviation scores

\begin{tabular}{|c|c|c|c|c|}
\hline Gender & & Mean & SD & SE mean \\
\hline Female & $86(58 \%)$ & 29.611 & 3.783 & 2.556 \\
\hline Male & $63(42 \%)$ & 27.633 & 2.671 & 1.445 \\
\hline
\end{tabular}

Table 4. Levene's test regarding experience between group in cooperative learning techniques

\begin{tabular}{|c|c|c|c|c|c|c|c|c|c|c|}
\hline \multicolumn{11}{|c|}{ Independent sample test } \\
\hline & & \multicolumn{4}{|c|}{$\begin{array}{c}\text { Levene's test for equality of } \\
\text { variances }\end{array}$} & \multicolumn{3}{|c|}{$\begin{array}{l}\text { t-test for equality of } \\
\text { variances }\end{array}$} & \multicolumn{2}{|c|}{$\begin{array}{c}95 \% \\
\text { confidence }\end{array}$} \\
\hline & & $\mathrm{F}$ & Sig. & $T$ & Df & \begin{tabular}{|c|} 
Sig. \\
$(2-$ \\
tailed)
\end{tabular} & $\begin{array}{c}\text { Mean } \\
\text { difference }\end{array}$ & $\begin{array}{c}\text { SE } \\
\text { difference }\end{array}$ & Lower & Upper \\
\hline Comparison between gender i & Equal variances assured & 9.334 & 0.0004 & 2.93 & 944 & $0.002^{\star \star}$ & 4.221 & 0.213 & 0.004 & 0.622 \\
\hline $\begin{array}{r}\text { cooperative learning techniques } \\
\text { culturally diverse classrooms }\end{array}$ & $\begin{array}{l}\text { Equal variances not } \\
\text { assured }\end{array}$ & & & 2.04 & 822.033 & $0.034^{\star \star}$ & 1.671 & 0.211 & 0.008 & 0.509 \\
\hline
\end{tabular}

${ }^{* *} p \leq .05$

Results of the t-test are shown in Tables 3 and 4. There are differences in the mean scores of experience of female educators in cooperative learning techniques in culturally diverse classrooms $(M=29.611, S D=3.783)$ which is statistically significantly higher ( $t=2.93, d f=994)$ at a two-tailed $(p=0.002$ and 0.034$)$ test compare to male educators $(M=27.633$, $\mathrm{SD}=2.671$ ). Overall, the results show that female educators were better equip and show greater experiences in cooperative learning techniques in culturally diverse classrooms which did enhanced learners' knowledge and learning in their respective schools.

Table 5: Effect size egarding experiences in cooperative learning techniques

\begin{tabular}{|c|c|c|c|c|c|}
\hline \multicolumn{7}{|c|}{ ANOVA } \\
\hline & Sum of squares & $D f$ & Mean squares & $F$ & Sig \\
\hline Between groups & 8721.619 & 125 & 2049.040 & 7.998 & $0.001^{* *}$ \\
\hline Within groups & 45266.8 & 891 & 801.196 & & \\
\hline Total & 53988.419 & 1016 & & & \\
\hline
\end{tabular}

These results in Table 5 indicated that females had moe experiences in cooperative learning techniques in culturally diverse classrooms by educator groups (between female educator groups, learners groups) is statistically significant $(p=$ $0.001)$, which indicated a modest effect $(8721.619 \div 45266.8=0.192)$ compared to male educators experiences in cooperative learning techniques in culturally diverse classroom settings.

\section{Discussion of Key Findings}

According to the results of the biographical section, $69 \%$ of educators have less than 9 years experience. According to Alexander (2004) and Mpisi (2010) inexperienced staff component doesn't associate easily with issues related to cultural diversity and may therefore find it difficult to teach integrated school environment. Furthermore $38.6 \%$ of educators have between 11-20 years experience. Most of these educators were trained in racially segregated training institutions, during the apartheid period. Additionally, these educators may find it extremely difficult to change their fixed and ingrained ways of teaching (Van Wyk 2008; Kivedo 2006). Oakley, Felder and Elhajj (2004) are of the opinion that cooperative learning can be viewed as a tool in enhancing teaching in integrated school environments. In these environments, learners should be provided with opportunities to discover, construct knowledge, develop new talents and skills. Teaching-learning interactions amongst learners and between learners and educators may be optimised in this way (Millis 2001). 
Cooperative learning as a crucial teaching strategy can be applied successfully by both experienced and novice teachers as a means of developing higher-order thought processes and equipping learners for the challenges of integrated school environments and society at large.

Studies done by Christison (1990) on the implementation of a cooperative learning programme on learners' performance in a particular training centre revealed that the application of cooperative learning as a teaching strategy has a positive effect on their achievement within group context. Learners within the group were responsible for the interdependent success of the group in question. Developing positive relations and interactions amongst learners of all racial groups according to studies executed by Johnson et al., (1994) and Nattiv et al. (1991) have proven that the application of cooperative learning in the classroom promotes and improves the self-esteem of all learners concerned. Students in cooperative groups seemed to be more liked by their classmates because of increased opportunities to interact during cooperative learning tasks. The development and learning of life skills as a cooperative learning strategy is not merely a situation where learners sit physically close to one another, discuss an assignment or assist other learners, but should involve mutual one-on-one cooperation and support Taylor (1991). Accepting responsibility for one's own learning process is of cardinal importance to learner development in the cooperative learning process. The assumption is that learners will be encouraged to accept responsibility for their own learning if granted the opportunity to become actively engaged during the teaching and learning process. Group members accept responsibility for the actions and cooperation of their fellow group members. In relation to the latter view, Bartlett (1995) and Christison (1990) content that learners' involvement in active learning activities depends on the extent to which they accept responsibility for their part in the learning process.

In summation, the outcomes of cooperative learning can improve academic performance and improved social and interpersonal relationships needed to facilitate effective teaching in cultural diverse integrated setting of the Northern Cape province. Through this process learners might construct personal meaning from concepts and principles and apply their understanding to different aspects of their lives and world views. Furthermore, learners can acquire knowledge, skills and values for lifelong learning situations in order to learn effectively and develop knowledge through diverse learning experiences. Cooperative learning opportunities tend to prepare learners more adequate for lifelong roles by means of motivation and practise. Moreover learners develop life competencies and roles by shared leadership responsibilities and tasks. Learners are taught, by means of class development and team-building sessions, to develop social skills and relationships prepare them to embrace issues related to human rights, inclusivity and social justice.

\section{Conclusion and Limitations of Study}

The authors conclude that the Northern Cape Department of Education needs to empower and capacitate educators in cooperative learning techniques. Furthermore it is incumbent upon educator training institutions to appropriately align their curricula and programmes to learner centred methods in which active teaching approaches such as cooperative learning is fully embraced. It is clear that cooperative learning can change the way learners interact and communicate in cultural diverse school settings whilst simultaneously also demonstrating the ability to master increased learning and social skills acquisition.

One must view the present study cautiously because of four limitations. The first limitation concerns the sample size which involved a small number of teachers $(n=148)$ and learners $(n=100)$ who participated in this study. Because of the restricted range of participants, in future research studies, we will include a more diverse and representative sample of participants. The second limitation is the time factor. This study was conducted during only a two week period. A longer investigation period (one year) would maybe yield different results. The third limitation is pedagogical content knowledge (PCK). This was a serious concern for some teachers and learners because of limited or lack of knowledge and learner teacher support materials (LTSM) to integrate the $C L$ teaching approach to enhance their praxis.

\section{References}

Alexander G. 2004. The design and evaluation of a staff development programme for amalgamated schools in The Northern Cape. Unpublished Ph. D Thesis. Bloemfontein. University of the Free State.

Aronson E., Blaney N., Stephan N, Sikes J, Snapp M. 1978. The jigsaw classroom. Beverley Hills, CA: Sage Publications Inc.

Artzt AF, Newman CM. 1990. Cooperative learning. Mathematics Teacher, 83(6): 448-54.

Bartlett, R.L. 1995. A flip of the coin, a roll of the die: An answer to the free-rider problem in economic instruction. Journal of Economic Education, 2: 131-139.

Christison, M.A. 1990. Co-operative learning in the EFL classroom. English Teaching Forum, XXVII(4): 6-9. 
Davidson N, O' Leary PW. 1990. How cooperative learning can enhance mastery teaching. Educational Leadership, 47(5): 30-33.

Dewey J. 1961. How we think. New York: Macmillan.

Dumas A. 2003. Cooperative learning: Response to diversity. California: Department of Education [Online] .www.cde.ca.gov/iasa.Retrieved: 12 February 2012

Felder. R M, Brent R. 2001. Effective strategies for cooperative learning. Journal of Cooperation and Collaboration in College Teaching 10(2), 69-75.

Haynes NM, Gebreyesus S. 1992. Cooperative learning: A case for African-American students. School Psychology Review 21(4),577585.

Hanekom M, Nel GO. 1991. Koöperatiewe leer as 'n aspek van kleingroepwerk in die primêre skool. Die Unie: 132-134

Johnson D.W, Johnson R.T. 1986. Action research: Cooperative learning in the science classroom. Science and Children, 24(2): 31-32.

Johnson D.W, Johnson R.T. 1987. How can we put cooperative learning into practice? Science Teacher, 54(6): 46-48.

Johnson DW, Johnson RT. 1992. Structuring cooperative learning: Lesson plans for teachers. New Brighton: Interaction Books Co.

Johnson, D.W., Johnson, R.T, Holubec, JE. 1994. Cooperative learning in the classroom. Virginia: Association for Supervision and Curriculum Development.

Johnson D.W, Johnson R.T., Smith., K.A. 1998. Making cooperative learning work. Theory into Practice 38(2), 6-72.

Jonassen D, Peck K, Wilson B. 1999. Learning with Technology: Constructivist Perspectives. Upper Saddle River, N.J: Prentice Hall, Inc.

Kagan S. 1988. Cooperative learning resources for teachers. San Juan Capistrano, CA: Resources for Teachers.

Khumalo K.H. 2001. The effects of cooperative learning on student performance in English as a second language with specific reference to Madadeni College of Education. MPhil dissertation, University of Stellenbosch.

Killen R. 2007. Effective teaching strategies for OBE teaching, $2^{\text {nd }}$ Edition. Boston: Social Science Press.

Kivedo C. 2006. A Psycho-educational investigation into the state of multicultural eduction and the design of a multicultural education frame work for Northern Cape schools. Unpublished Ph. D Thesis. Bloemfontein. University of the Free State.

Kohn A. 1991. Group grading grubbing versus cooperative learning. Educational Leadership, 48 (5): 83-87.

Learning Theories. 2008. Cognitivism at Learning-Theories.com. Retrieved March 15th, 2012 at http://www.learningtheories.com/cognitivism.html

Leedy P.D, Ormrod J.E. 2001. Practical Research. Planning and Design, $7^{\text {th }}$ Edition. New Jersey: Merrill Prentice Hall.

Le Roux J. 1997. Multicultural education: what every teacher should know. Pretoria: Kagiso

Lotan R.A, Witcomb J.A 1998. Introduction. In: Schulman, J., Lotan, R.A. \& Wicomb, J.A. (Eds), Groupwork in diverse classrooms, a casebook for educators. New York: Columbia University Teachers' College Press.

Manera E.S, Glockhamer H. 1989. Co-operative learning: Do students own the content? Action in Teacher Education, 10(4): 53-56.

Meier C. 2005. Addressing problems in integrated schools: learner's teachers' perceptions regarding viable solutions for learners' academic problems. South African Journal of Education 25(3), 170 - 177.

Millis J. 2001. Cooperative learning: It's here to stay. Essays on Teaching Excellence 12(8)1-4.

Mpisi A. 2010. The scholastic experience of black learners in multicultural FET schools in the Northern Cape. Unpublished Ph. D Thesis. Bloemfontein. University of the Free State.

Nastasi B.K, Clements D.H. 1991. Research on cooperative learning: Students read and write? Illinois: Urbana.

National Department of Education (NDE). 2003a. Constitution of South Africa. Pretoria: Government Printers.

National Department of Education (NDE). 2003b. Phasing in OBE into the FET band: Implementation strategies (2004-2006). Pretoria: Government Press.

Nattiv A \& Winitzky N, Drickey R. 1991. Using cooperative learning with pre-service elementary and secondary education students. Journal of Teacher Education, 42(3): 216-225.

Oakley B, Felder R.M, Brent R, Elhaij I. 2004. Turning student groups into effective teams. Journal of Student-Centred Learning 2(1), 934.

Okebukola P. 1985. The relative effectiveness of cooperativeness and competitive interaction techniques in strengthening students' performance in science classes. Science Education, 69: 501-209.

Putnam J.W. 1998. The movement towards teaching and learning in inclusive classrooms. In: Putnam, J.W. (Ed). Cooperative learning and strategies for inclusion- celebrating diversity in classroom, 2nd Edition, Baltimore, M.D: Paul H. Brookes.

Sapon-Shevin M, Schniedewind N. 1992. If cooperative learning's the answer, what are the questions? Journal of Education, $174(2)$ : $11-$ 37.

Sharan S. 1990. Cooperative learning: Theory and research. New York: Praeger.

Slavin R.E. 1980. Cooperative learning. Review of Educational Research, 50(2): 315-342.

Slavin R.E. 1987a. Cooperative learning: Can students help students learn? Instructor 96 (7), 74-76.

Slavin R.E. 1987b. Cooperative learning: Where behavioural and humanistic approaches to classroom motivation meet. The Elementary School Journal, 88(1): 29-35.

Smith R.A. 1987. The teacher's view on cooperative learning. Phi Delta Kappan, 68(9): 663-666.

Smith K.A. 2000. Going deeper: Formal small-group learning in large classes. In: J MacGregor, JL Cooper, KA Smith \& P Robinson (eds.). Strategies for energizing large classes: From small groups to learning communities: New Directions for Teaching and Learning, 81: 25-46. 
Taylor C.A. 1991. Koöperatiewe leer: ' $n$ vorm van kompenseringsonderwys in ' $n$ tegnologiese era. Suid Afrikaanse Tydskrif vir Opvoedkunde, 11(4): 244-247.

Van der Horst H, McDonald R. 1997. Outcomes-based education: A teacher's manual. Pretoria: Kagiso Publishers.

Van Wyk M.M. 2008. The use of cooperative learning in economics in the further education and training phase in the Free State Provice. Unpublished Ph. D Thesis. Bloemfontein. University of the Free State.

Ziegler S. 1981.The effectiveness of cooperative learning teams for increasing cross-ethnic friendship: Additional evidence. Human Organisation, 40: 264-268. 